\title{
Retraction notice to: 'The unusual practices within some Neo-Pentecostal churches in South Africa: Reflections and recommendations', HTS Teologiese Studies/Theological Studies 73(3), a4656
}

\begin{tabular}{|c|c|}
\hline \multicolumn{2}{|c|}{$\begin{array}{l}\text { Author: } \\
\text { Mookgo S. Kgatle }\end{array}$} \\
\hline \multicolumn{2}{|c|}{$\begin{array}{l}\text { Affiliation: } \\
{ }^{1} \text { Department of New } \\
\text { Testament Studies, Faculty } \\
\text { of Theology, University } \\
\text { of Pretoria, Pretoria, } \\
\text { South Africa }\end{array}$} \\
\hline \multicolumn{2}{|c|}{$\begin{array}{l}\text { Corresponding author: } \\
\text { Mookgo Kgatle, } \\
\text { kgatles@yahoo.com }\end{array}$} \\
\hline \\
\hline \multicolumn{2}{|c|}{$\begin{array}{l}\text { How to cite this article: } \\
\text { Kgatle, M.S., 2021, } \\
\text { 'Retraction notice to: "The } \\
\text { unusual practices within } \\
\text { some Neo-Pentecostal } \\
\text { churches in South Africa: } \\
\text { Reflections and } \\
\text { recommendations", } \\
\text { HTS Teologiese Studies/ } \\
\text { Theological Studies 73(3), } \\
\text { a4656', HTS Teologiese } \\
\text { Studies/Theological Studies } \\
\text { 77(1), a6611. https://doi. } \\
\text { org/10.4102/hts.v77i1.6611 }\end{array}$} \\
\hline \multicolumn{2}{|c|}{$\begin{array}{l}\text { Doi of original article: } \\
\text { https://doi.org/10.4102/hts. } \\
\text { v73i3.4656 }\end{array}$} \\
\hline \multicolumn{2}{|c|}{$\begin{array}{l}\text { Copyright: } \\
\text { (c) 2021. The Authors. } \\
\text { Licensee: AOSIS. This V } \\
\text { is licensed under the } \\
\text { Creative Commons } \\
\text { Attribution License. }\end{array}$} \\
\hline \multicolumn{2}{|l|}{ Read online: } \\
\hline 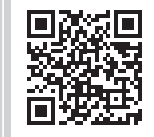 & $\begin{array}{l}\text { Scan this QR } \\
\text { code with your } \\
\text { smart phone or } \\
\text { mobile device } \\
\text { to read online. }\end{array}$ \\
\hline
\end{tabular}

Reason: The article, Kgatle, M.S., 2017, 'The unusual practices within some Neo-Pentecostal churches in South Africa: Reflections and recommendations', HTS Teologiese Studies/Theological Studies 73(3), a4656. https://doi.org/10.4102/hts.v73i3.4656, published on 29 September 2017 in HTS Teologiese Studies/Theological Studies has been retracted by the journal's Editor-in-Chief, Prof. Andries van Aarde, because of sections of plagiarised text. Verbatim work was cited but presented to the readers as paraphrased from the original, providing the impression that the lifted passages were the author's own words. The verbatim text directly affects the findings of the paper and could not be removed. The article is hereby retracted to correct the publication record.

We apologise for any inconvenience to the authors and readers of HTS Teologiese Studies/Theological Studies. 